\title{
Short communication: Measuring the angiotensin-converting enzyme inhibitory activity of an 8-amino acid (8mer) fragment of the $\mathrm{C} 12$ antihypertensive peptide ${ }^{1}$
}

\author{
Moushumi Paul, ${ }^{* 2}$ John G. Phillips, $†$ and John A. Renye Jr. ${ }^{* 2,3}$ \\ *Dairy and Functional Foods Research Unit, Eastern Regional Research Center, and \\ †Office of the Area Director, North Atlantic Area, Agricultural Research Service, USDA, 600 E. Mermaid Lane, Wyndmoor, PA 19038
}

\section{ABSTRACT}

An 8-AA (8mer) fragment (PFPEVFGK) of a known antihypertensive peptide derived from bovine $\alpha_{\mathrm{S}_{1}}$-casein (C12 antihypertensive peptide) was synthesized by microwave-assisted solid-phase peptide synthesis and purified by reverse phase HPLC. Its ability to inhibit angiotensin-converting enzyme (ACE) was assessed and compared with that of the parent 12 mer peptide (FFVAPFPEVFGK) to determine the effect of truncating the sequence on overall hypotensive activity. The activity of the truncated 8 mer peptide was found to be almost 1.5 times less active than that of the $12 \mathrm{mer}$, with ACE-inhibiting $\mathrm{IC}_{50}$ (half-maximal inhibitory concentration) values of 108 and $69 \mu M$, for the 8 mer and $12 \mathrm{mer}$, respectively. Although the 8 mer peptide is less active than the original 12 mer peptide, its overall activity is comparable to activities reported for other small proteins that elicit physiological responses within humans. These results suggest that microbial degradation of the 12mer peptide would not result in a complete loss of antihypertensive activity if used to supplement fermented foods and that the stable 8mer peptide could have potential as a blood pressure-lowering agent for use in functional foods.

Key words: antihypertensive peptide, bovine milk, solid-phase peptide synthesis, 8-amino acid peptide

\section{Short Communication}

Being able to increase the nutritional and healthpromoting properties of food using bovine milk-derived ingredients is a challenge that has attracted a great

\footnotetext{
Received September 23, 2015.

Accepted November 20, 2015.

${ }^{1}$ Mention of trade names or commercial products in this publication is solely for the purpose of providing specific information and does not imply recommendation or endorsement by the US Department of Agriculture.

${ }^{2}$ These authors contributed equally to this study.

${ }^{3}$ Corresponding author: john.renye@ars.usda.gov
}

deal of attention recently. Many bioactive compounds derived from milk proteins exhibit potential as functional food ingredients aimed at combating various conditions that can be controlled through diet, such as cardiovascular disease, type II diabetes, and obesity (Korhonen, 2009). These active peptides are hydrolytically released from the parent protein upon treatment with digestive enzymes, bacteria-associated proteases, or other proteases (Korhonen and Pihlanto, 2006). The resulting peptides display a wide variety of in vitro biological activities, including antihypertensive activities (Nagpal et al., 2011). Based on this broad spectrum of activities, there is great potential for the application of these peptides in the production of functional dairy foods.

Several studies have illustrated the correlation between dairy consumption and lowering of blood pressure (Lopez-Fandino et al., 2006; Jauhiainen and Korpela, 2007) and have identified specific peptides with angiotensin-I-converting enzyme (ACE) inhibitory activity (Korhonen and Pihlanto, 2006). Specifically, an $\alpha_{S 1}$-casein-derived 12-AA peptide $\mathrm{f}(23-34)$ with the sequence FFVAPFPEVFGK (12mer) has an inhibitory effect on ACE (Maruyama et al., 1987; Karaki et al., 1990; Townsend, et al., 2004) and has been reported to reduce systolic and diastolic blood pressure in human studies (Sekiya et al., 1992; Townsend et al., 2004; Cadée et al., 2007). The health effects of this peptide (also called $\mathrm{C} 12$ antihypertensive peptide) have been confirmed by the European Food Safety Authority Panel on Dietetic Products, Nutrition and Allergies (EFSA, 2010). Some food products have been developed that have utilized milk-derived ACE-inhibitory peptides, including Ameal S (Calpis Co. Ltd., Tokyo, Japan), a tablet-form sour milk product on the market in Japan (Nakamura et al., 1995; Hayes et al., 2007). To date, however, antihypertensive compounds such as the 12 mer have not been incorporated into any available fermented dairy products such as cheese or yogurt.

Because it is derived from bovine milk proteins, dairy foods such as yogurt may be an ideal delivery vehicle for 
the 12 mer antihypertensive peptide. The major limitation in this application is the presence of the Streptococcus thermophilus and Lactobacillus delbrueckii ssp. bulgaricus starter cultures used for milk fermentation. Cell-associated peptidases of these lactic acid bacteria (LAB) may inactivate the bioactive peptides by hydrolyzing them to AA (Gilbert et al., 1996; Siezen, 1999; Fernandez-Espla et al., 2000; Courtin et al., 2002). Previous work (Paul and Somkuti, 2009) has shown that the 12 mer peptide is significantly degraded in the presence of various $S$. thermophilus and $L$. delbrueckii ssp. bulgaricus cultures, resulting in an 8-AA (8mer) by-product with the sequence PFPEVFGK, which is relatively resistant to further proteolysis. Therefore, this study characterized and compared the antihypertensive properties of the 8 mer peptide and the parent 12 mer peptide to determine if it would be feasible to use either peptide to improve the functional value of fermented dairy foods.

The 8mer degradation product was generated by microwave-assisted solid-phase synthesis using a CEM Liberty 1 synthesizer (CEM Corporation, Matthews, NC). General peptide synthesis and cleavage protocols were followed (Cavalluzzo et al., 2013), with the crude samples analyzed by matrix-assisted laser desorptionionization time-of-flight mass spectrometry (MALDITOF MS). The sample was further purified by semipreparative $\mathrm{C} 18$ reverse-phase column chromatography (Alltech, Columbia, MD; $10 \times 250 \mathrm{~mm}$ column with 10$\mu \mathrm{m}$ particle size) using an Agilent 1200 HPLC system (Agilent Technologies, Santa Clara, CA) and a linear gradient from 5 to $100 \%$ B (95-0\% A) over 60 min at a flow rate of $4.7 \mathrm{~mL} / \mathrm{min}$, where A was water with $0.1 \%$ trifluoroacetic acid (TFA) and B was acetonitrile with $0.1 \%$ TFA, and shown to contain a single peak (Figure 1). Reverse phase (RP)-HPLC fractions were further analyzed by MALDI-TOF MS and showed the presence of a peptide with the expected mass of 920.5 atomic mass units (amu; Figure 2).

A preparation of the parent 12 mer peptide was previously obtained from SynPep (Dublin, CA) and used as a control for comparison of ACE-inhibitory activity. A stock solution of commercial ACE from rabbit lung (Sigma-Aldrich, St. Louis, MO) was prepared in reaction buffer (50 mM Tris-HCl, $\mathrm{pH} 7.5,300 \mathrm{~m} M \mathrm{NaCl})$ to give a final concentration of $0.25 \mathrm{U} / \mathrm{mL}$. Inhibition of ACE activity was determined using the method previously published by Paul and Van Hekken (2011). Varying amounts of the 12 mer peptide (final concentrations of $0-0.33 \mathrm{mg} / \mathrm{mL}$ ) were preincubated with $4 \mu \mathrm{L}$ of ACE at $37^{\circ} \mathrm{C}$ for $30 \mathrm{~min}$, after which $5 \mu \mathrm{L}$ of the substrate FAPGG $\{N-3$ (-[2-furylacryloyl]-Phe-Gly-Gly); $100 \mu M$ stock $\}$ was added and the reaction was carried out for an additional $40 \mathrm{~min}$. The reaction was stopped by the

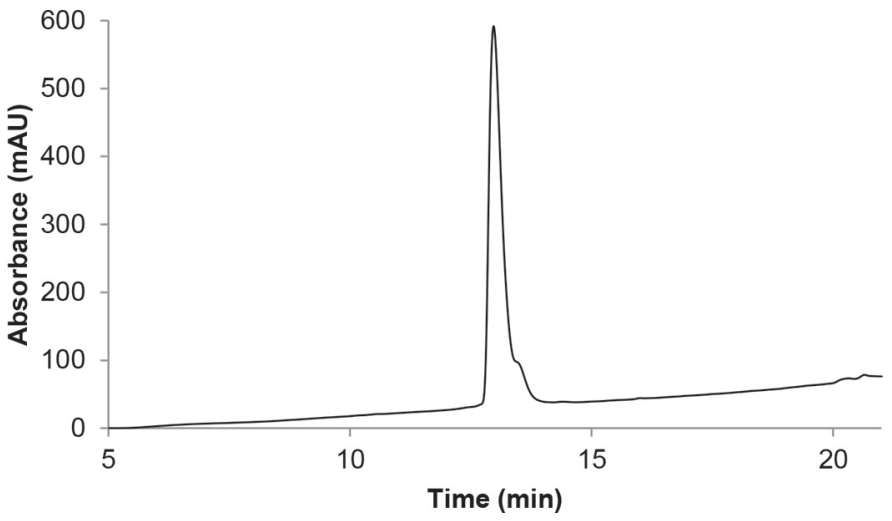

Figure 1. Reverse phase-HPLC chromatogram of 8-AA (8mer) peptide. $\mathrm{mAU}=$ milli-absorbance units.

addition of $5 \mu \mathrm{L}$ of TFA (10\%) and FAPGG hydrolysis by ACE was monitored by HPLC (Figure 3 ). The halfmaximal inhibitory concentration $\left(\mathbf{I C}_{50}\right)$ value for the 12 mer was calculated from the inhibition data that was collected and found to be $0.095 \mathrm{mg} / \mathrm{mL}$, corresponding to $69.0 \mu M$ (using the peptide molecular mass of 1,384.6 $\mathrm{g} / \mathrm{mol}$ ). This value is consistent with the value of 77 $\mu M$ previously reported by Maruyama et al. (1987).

Similar amounts of the 8 mer peptide (final concentration $0-0.35 \mathrm{mg} / \mathrm{mL}$ ) were tested for inhibiting ACE activity (Figure 4 ). The $\mathrm{IC}_{50}$ value for the 8 mer was calculated to be $0.099 \mathrm{mg} / \mathrm{mL}$, corresponding to 108 $\mu M$ (using the peptide molecular mass of $920.1 \mathrm{~g} /$ mol). This value corresponds to an efficacy about 1.5 times less than that of the $12 \mathrm{mer}$. It has been reported,

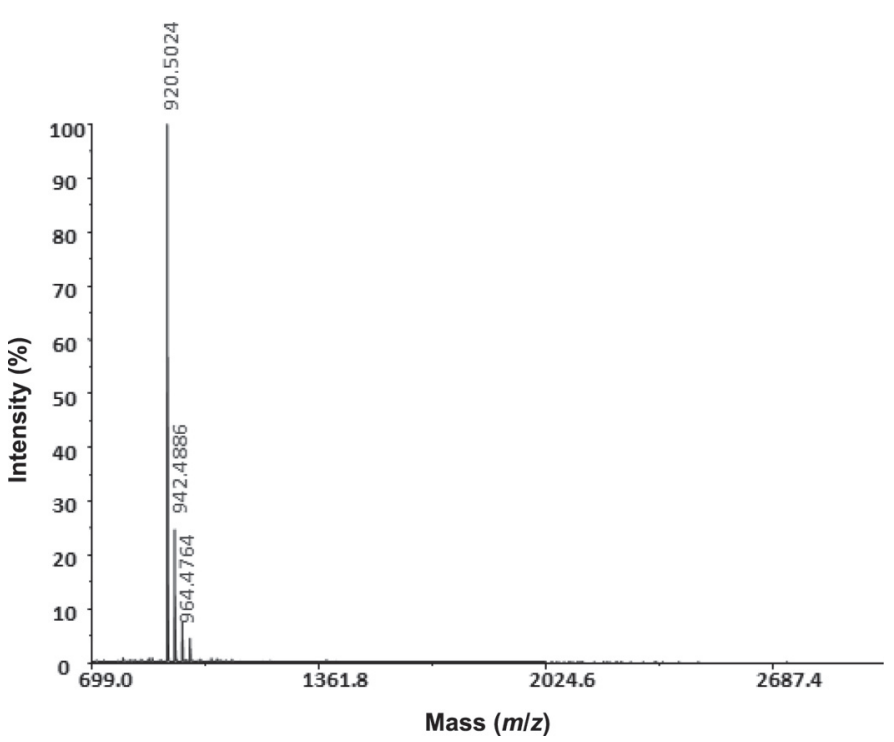

Figure 2. Matrix-assisted laser desorption/ionization-time-of-flight MS data analysis of purified 8-AA (8mer) peptide $(\mathrm{m} / z=920.5$ atomic mass units corresponds to 8 mer mass). 


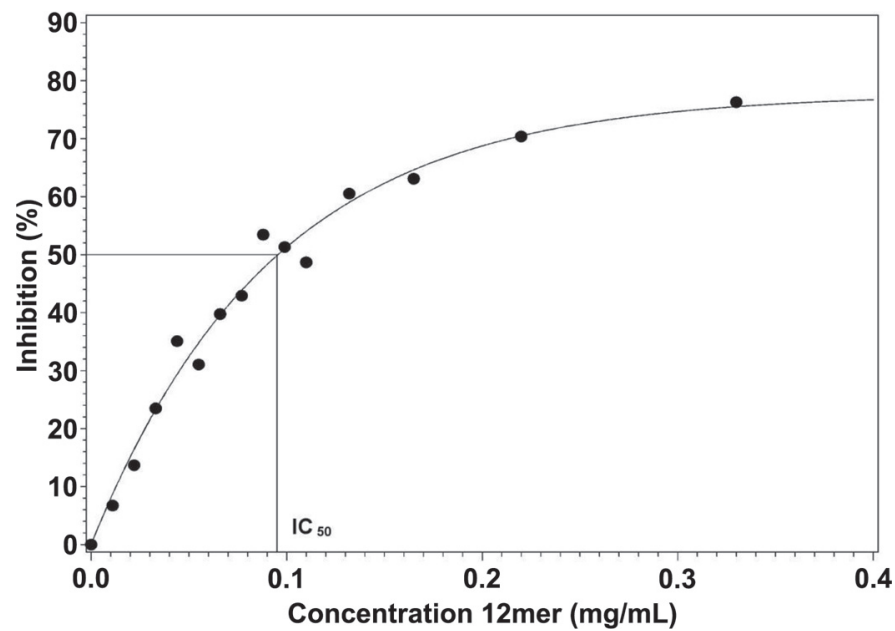

Figure 3. Angiotensin-converting enzyme inhibition curve of 12 AA (12mer) peptide with an incubation time of $40 \mathrm{~min}$ with the calculated half-maximal inhibitory concentration $\left(\mathrm{IC}_{50}\right)$ value $(0.096 \mathrm{mg} /$ $\mathrm{mL}$ ) indicated.

however, that other antihypertensive peptides derived from food with $\mathrm{IC}_{50}$ values in the range of 100 to 500 $\mu M$ may retain activity and elicit physiological effects in humans following oral administration (Sekiya et al., 1992). This suggests that the stable 8mer peptide may retain enough physiological activity to be considered a functional food ingredient.

There is interest in incorporating bioactive compounds into foods to enhance their overall nutritive or health benefits. Bioactive compounds that are food-derived are considered very attractive as they are intrinsically considered safe for consumption because

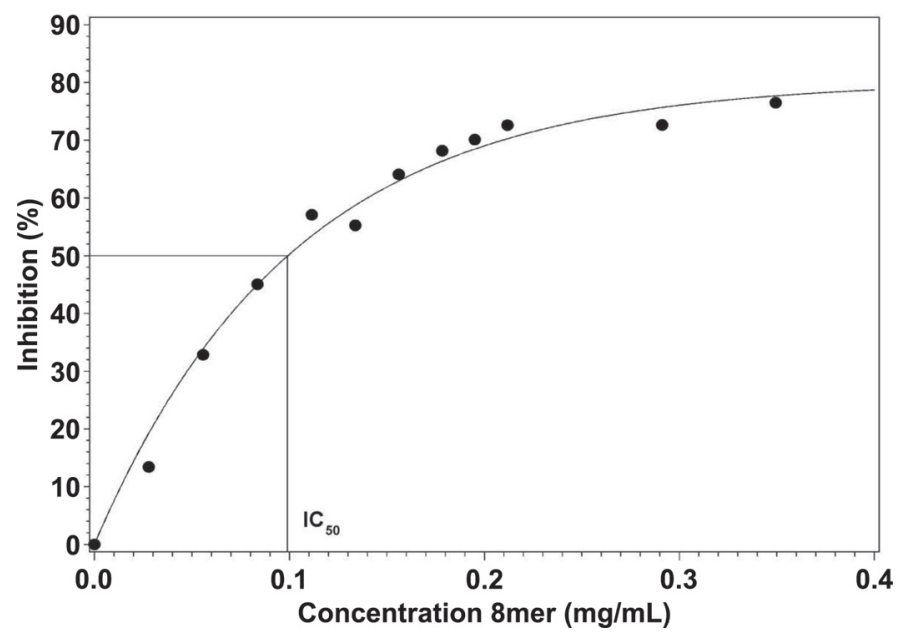

Figure 4. Angiotensin-converting enzyme inhibition curve of 8-AA (8mer) peptide with an incubation time of $40 \mathrm{~min}$ with the calculated half-maximal inhibitory concentration $\left(\mathrm{IC}_{50}\right)$ value $(0.099 \mathrm{mg} / \mathrm{mL})$ indicated. they come from foods. Therefore, the ability to fortify foods with these bioactive peptides has become increasingly appealing. This is especially true with milk and dairy products, which have been reported to be rich sources of bioactive compounds (Gobbetti et al., 2002; Pellegrini, 2003; FitzGerald et al., 2004; Zimecki and Kruzel, 2007; Chen et al., 2009; Korhonen, 2009).

Previous studies showing the effectiveness of the C12 peptide in reducing blood pressure in human subjects were carried out by administering the peptide in tablet form (Townsend et al., 2004; Cadée et al., 2007). However, it has been speculated that this peptide could also serve as a functional food ingredient to increase the health benefits of dairy foods such as yogurt. A major concern about its effectiveness as a functional food ingredient centers on its stability within products that contain viable LAB cultures (Paul and Somkuti, 2009). Paul and Somkuti (2009) reported that the C12 antihypertensive peptide was degraded by microbial proteases, and that the resulting 8mer degradation product was fairly robust under conditions that mimic the production of yogurt. Although proteolysis was most efficient under conditions that mimicked the yogurt fermentation step, with 66 to $99 \%$ of the peptide degraded within $4 \mathrm{~h}$, peptide degradation was also observed at $\mathrm{pH} 4.5$, with 22 to $34 \%$ of the $\mathrm{C} 12$ peptide degraded within $60 \mathrm{~min}$ (Paul and Somkuti, 2009). These results suggest that the timing of addition of the antihypertensive peptide to the fermented food will influence its stability. For example, the peptide could be added into yogurt during a post-fermentation step, such as when fruit is incorporated into Swiss-style yogurts, or by including it with other supplemental food ingredients such as oatmeal or granola, which are kept separate from the yogurt until just before consumption (e.g., flip-top yogurt packaging). However, once the peptide is exposed to the cultures, the potential for proteolysis exits. The results from our study show that the predominant 8 mer degradation product retains a level of antihypertensive activity comparable to that of other antihypertensive peptides that have elicited physiological responses within hosts after oral administration (Sekiya et al., 1992). The results from this study demonstrate the potential for using the $\mathrm{C} 12$ peptide as a functional food ingredient because the degradation product retains a physiologically relevant level of antihypertensive activity. Moreover, our results suggest that the 8mer degradation product itself could serve as a bioactive ingredient. Further research is needed on the overall bioavailability of both the $12 \mathrm{mer}$ and $8 \mathrm{mer}$ peptides after exposure to conditions that mimic the human digestive system to determine their true potential as ingredients for improving the functional value of dairy foods. 


\section{ACKNOWLEDGMENTS}

The authors acknowledge Dennis Steinberg (USDAAgricultural Research Service-Eastern Regional Research Center) for his help with peptide synthesis and Alberto Nuñez (USDA-Agricultural Research ServiceEastern Regional Research Center) for collecting mass spectrometry data.

\section{REFERENCES}

Cadée, J. A., C.-Y. Chang, C.-W. Chen, C.-N. Huang, S.-L. Chen, and C.-K. Wang. 2007. Bovine casein hydrolysate (C12 peptide) reduces blood pressure in prehypertensive subjects. Am. J. Hypertens. 20:1-5.

Cavalluzzo, C., F. Christ, A. Voet, A. Sharma, B. K. Singh, K. Y. Zhang, E. Lescrinier, M. De Maeyer, Z. Debyser, and E. Van der Eycken. 2013. Identification of small peptides inhibiting the integrase-LEDGF/p75 interaction through targeting the cellular cofactor. J. Pept. Sci. 19:651-658.

Chen, Z. Y., C. Peng, R. Jiao, Y. M. Wong, N. Yang, and Y. Huang. 2009. Anti-hypertensive nutraceuticals and functional foods. J. Agric. Food Chem. 57:4485-4499.

Courtin, P., V. Monnet, and F. Rul. 2002. Cell-wall proteinases PrtS and PrtB have a different role in Streptococcus thermophilus/ Lactobacillus bulgaricus mixed cultures in milk. Microbiology 148:3413-3421.

EFSA. 2010. Scientific opinion on the substantiation of health claims related to a C12 peptide (Phe-Phe-Val-Ala-Pro-Phe-Pro-Glu-ValPhe-Gly-Lys) and maintenance of normal blood pressure (ID 1483 , 3130) pursuant to Article 13(1) of Regulation (EC) No 1924/2006. EFSA J. 8:1478-1489.

Fernandez-Espla, M. D., P. Garault, V. Monnet, and F. Rul. 2000. Streptococcus thermophilus cell wall-anchored proteinase: Release, purification, and biochemical and genetic characterization. Appl. Environ. Microbiol. 66:4772-4778.

FitzGerald, R. J., B. A. Murray, and D. J. Walsh. 2004. Hypotensive peptides from milk proteins. J. Nutr. 134:980S-988S.

Gilbert, C., D. Atlan, B. Blanc, R. Portailer, J. E. Germond, L. Lapierre, and B. Mollet. 1996. A new cell surface proteinase: Qequencing and analysis of the prtB gene from Lactobacillus delbruekii ssp. bulgaricus. J. Bacteriol. 178:3059-3065.

Gobbetti, M., L. Stepaniak, M. De Angelis, A. Corsetti, and R. Di Cagno. 2002. Latent bioactive peptides in milk proteins: Proteolytic activation and significance in dairy processing. Crit. Rev. Food Sci. Nutr. 42:223-239.

Hayes, M., C. Stanton, H. Slattery, O. O'Sullivan, C. Hill, G. F. Fitzgerald, and R. P. Ross. 2007. Casein fermentate of Lactobacil- lus animalis DPC6134 contains a range of novel propeptide angiotensin-converting enzyme inhibitors. Appl. Environ. Microbiol. 73:4658-4667.

Jauhiainen, T., and R. Korpela. 2007. Milk peptides and blood pressure. J. Nutr. 137:825S-829S.

Karaki, H., K. Doi, S. Sugano, H. Uchiwa, R. Sugai, U. Murakami, and S. Takemoto. 1990. Antihypertensive effect of tryptic hydrolysate of milk casein in spontaneously hypertensive rats. Comp. Biochem. Physiol. C 96:367-371.

Korhonen, H. 2009. Milk-derived bioactive peptides: From science to applications. J. Funct. Foods 1:177-187.

Korhonen, H., and A. Pihlanto. 2006. Bioactive peptides: Production and functionality. Int. Dairy J. 16:945-960.

Lopez-Fandino, R., J. Otte, and J. van Camp. 2006. Physiological, chemical and technological aspects of milk-protein-derived peptides with antihypertensive and ACE-inhibitory activity. Int. Dairy J. 16:1277-1293.

Maruyama, S., H. Mitachi, J. Awaya, M. Kurono, N. Tomizuka, and H. Suzuki. 1987. Angiotensin I-converting enzyme inhibitory activity of the C-terminal hexapeptide of $a_{\mathrm{S}_{1}}$-casein. Agric. Biol. Chem. 51:2557-2561.

Nagpal, R., P. Behare, R. Rana, A. Kumar, M. Kumar, S. Arora, F Morotta, S. Jain, and H. Yadav. 2011. Bioactive peptides derived from milk proteins and their health beneficial potentials: An update. Food Funct. 2:18-27.

Nakamura, Y., N. Yamamoto, K. Sakai, and T. Takano. 1995. Antihypertensive effect of sour milk and peptides isolated from it that are inhibitors to angiotensin I-converting enzyme. J. Dairy Sci. 78:1253-1257.

Paul, M., and G. A. Somkuti. 2009. Degradation of milk-based bioactive peptides by yogurt fermentation bacteria. Lett. Appl. Microbiol. 49:345-350.

Paul, M., and D. L. Van Hekken. 2011. Short communication: Assessing antihypertensive activity in native and model Queso Fresco cheeses. J. Dairy Sci. 94:2280-2284.

Pellegrini, A. 2003. Antimicrobial peptides from food proteins. Curr. Pharm. Des. 9:1225-1238.

Sekiya, S., Y. Kobayashi, E. Kita, Y. Imamura, and S. Toyama. 1992 Antihypertensive effects of tryptic hydrolysate of casein on normotensive and hypertensive volunteers. J. Jpn. Soc. Nutr. Food Sci 45:513-517.

Siezen, R. J. 1999. Multi-domain, cell-envelope proteinases of lactic acid bacteria. Antonie Van Leeuwenhoek 76:139-155.

Townsend, R. R., C. B. McFadden, V. Ford, and J. A. Cadee. 2004. A randomized, double-blind, placebo-controlled trial of casein protein hydrolysate (C12 peptide) in human essential hypertension. Am. J. Hypertens. 17:1056-1058.

Zimecki, M., and M. L. Kruzel. 2007. Milk-derived proteins and peptides of potential therapeutic and nutritive value. J. Exp. Ther. Oncol. 6:89-106. 